\title{
Effect of Processing on the Chemical and Anti-Nutritional Properties of Cassava Leaves (Sweet and Bitter Varieties)
}

\author{
Ujong Anim Ekpo*, Deede Faith Baridia \\ Department of Food Science and Technology, Rivers State University, Nkpolu Oroworukwo, P.M.B., 5080, Port \\ Harcourt, Rivers State, Nigeria
}

*Corresponding Author: Ujong Anim Ekpo, Department of Food Science and Technology, Rivers State University, Nkpolu Oroworukwo, P.M.B., 5080, Port Harcourt, Rivers State, Nigeria.

\begin{abstract}
The effect of processing on the chemical and anti-nutritional properties of cassava leaves was investigated. Leaves of cassava (bitter and sweet varieties) were subjected to boiling, steaming, microwaving, dry-roasting and unprocessed cassava leaf which was used as control. The leaves were analyzed for proximate, mineral and anti-nutritional composition using standard methods. The proximate analysis revealed that microwaving resulted to a significantly ( $p<0.05)$ higher retention of ash $(3.28 \%$ and $2.74 \%)$, protein $(11.3 \%$ and $12.08 \%)$, and carbohydrate (12.95\% and 19.45\%) for sweet and bitter cassava leaves, respectively while the moisture content increased significantly $(p<0.05)$ for boiling. Result of the mineral analysis also revealed that boiling and steaming resulted to a significant $(p<0.05)$ decrease in magnesium, iron, zinc, calcium and potassium contents while these nutrients were highly retained following microwaving except for zinc which was highest in the control sample. Anti-nutrient analysis result showed that phytate, oxalate and tannins were significantly $(p<0.05)$ higher with microwaved cassava leaves while boiling caused a significant $(p<0.05)$ reduction. However, the levels of these anti-nutrients were low. This study therefore shows that processing methods such as boiling tremendously reduced the anti-nutrients with significant loss in the nutrients while microwaving retained the nutrient content with acceptable level of anti-nutritional factors.
\end{abstract}

Keywords: Boiling, Cassava leaves, dry-roasting, microwaving, steaming.

\section{INTRODUCTION}

Cassava (Manihot esculenta crantz) is a tropical woody shrub and a dicotyledonous plant belonging to the botanical family Euphorbiaceace. It is an important staple food crop in the over 900 million of people in the world [1]. It is the third most important food source in the tropical world after rice and maize [2]. It is used as a food crop in Africa and its potentials has increased during and after the 1984 Famine [1]. The cassava roots, young leaves and the tips of stems can all be consumed. In rural areas in Nigeria, cassava roots are usually consumed boiled or baked while people with more economical means tend to eat cassava roots as fried chips or as a snack food [3]. Apart from its food uses, cassava can be used in the industry for the production of starch which is applicable in many types of product such as confectionery, sweeteners, glues, plywood, textiles, paper, monosodium glutamate and drugs. Products from cassava also include chips and pellets which are used in animal feed and alcohol production [4].

Cassava leaves are green vegetable which has long been recognized as food for most Nigerians and other developed countries. They are a byproduct at the time of harvesting the roots. They have high protein content and a relatively good profile of essential amino acids which makes it a potential alternative protein resource for both humans and animal [2]. The leaves have been reported to be rich in minerals, proteins, vitamin and carotenes depending on its variety [5]. Cassava leaves are accepted as vegetables in Nigeria, Sierra Leone and Zaire. They are sometimes combined with non-toxic indigenous vegetables such as fluted pumpkin leaves in the preparation of yam porridge. Despite its nutritional value, toxicant and anti-nutrients which precipitate the unavailability of nutrient of the body cells are limiting factors to its widespread use as food in Nigeria. 
The level of these anti-nutrients in cassava leaves varied depending on the variety and has been reported to be 6 times higher than in the roots [2]. Studies by Jamil and Bujang [6] have identified presence of cyanides and tannins in cassava leaves. Ngudi et al. [7] also reported that cassava leaves contains $15-20$ times more cyanide than cassava tubers. Ravindran and Ravindran [8] also reported that cassava leaves have cyanide content of $52.9 \mathrm{mg}$, HCN per $100 \mathrm{~g}$, high tannin and phytin levels of $9.7 \mathrm{~g}$ per $100 \mathrm{~g}$ DM and 192.0mg per 100, respectively and their concentration decreases in the leaves with the maturity showing a maximum decline in lysine. Therefore, proper treatment must be employed prior to consumption to reduce these antinutrients in the leaves. Previous studies by Bradbury and Denton [9] have used two methods (pounding and boiling) for the removal of cyanogens from cassava leaves at room temperature and intact cassava leaves at $50^{\circ} \mathrm{C}$, which produced residual total cyanide contents of $3-8 \%$. They also reported that pounding diminishes cyanogen content by $63 \%$ to $73 \%$ while pounding/crushing followed by boiling eliminates $97 \%$ of the cyanogenic. However, these processes led to loses of certain vitamins and proteins.

In order for cassava leaves to be utilized fully, there is a need to develop simple and efficient processing methods that would reduce the level of anti-nutritional factors in cassava leaves to the level that they are acceptable for human consumption. Therefore, this study aimed at evaluating the effect of processing methods on the chemical and anti-nutritional factors of two cassava leaf varieties (sweet and bitter cassava). It is hoped that the data generated from this study will help in establishing the best processing method with higher nutrient retention for cassava leaves.

\section{Materials AND Method}

\subsection{Sample Collection}

Cassava leaves (sweet and bitter varieties) were obtained from Assension high school farm, Ogale in Eleme Local Government of Rivers state. Chemicals were collected from the Department of Food Science and Technology Laboratory, Rivers State University and were all of analytical grade.

\subsection{Sample Preparation}

The following treatments were conducted on each of the variety of cassava leaves:

\subsubsection{Boiling}

Young green cassava leaves ( $300 \mathrm{~g})$ were sorted to remove pest infected leaves, properly washed with salt, sliced and poured into $1200 \mathrm{ml}$ of boiling water $\left(100^{\circ} \mathrm{C}\right)$. The leaves were allowed to boil for $20 \mathrm{~min}$ to detoxify the toxic content of the cassava leave. After boiling, the water was drained, allowed to cool, dried in an air oven at $60^{\circ} \mathrm{C}$ for $12 \mathrm{hrs}$. The dried leaves were finally milled using Sos cyclocet 1093 milling machine.

\subsubsection{Steaming}

Young green cassava leaves (300 g) were sorted, properly washed with salt, sliced, and placed on a food steamer which generated steam by means of steam escape for 20-30 mins. Thereafter, it was cooled, dried in an air oven for $12 \mathrm{hrs}$ at $60^{\circ} \mathrm{C}$ and the dried leaves were finally milled using Sos cyclocet 1093 milling machine.

\subsubsection{Microwaving}

Young green cassava leaves (300 g) were sorted, washed with salt, drained and cooked in microwave for $5 \mathrm{~min}$. Thereafter, it was oven dried at $60^{\circ} \mathrm{C}$ for $12 \mathrm{hrs}$. The dried leaves were finally milled with Sos milling machine.

\subsubsection{Dry roasting}

Two handfuls of young cassava leaves were sorted washed with salt, drained using a filter drainer. The drained cassava leaves were roasted dry in a pan at $180^{\circ} \mathrm{C}$ for $5-10 \mathrm{~min}$ after which it was cooled, dried in an air oven at $60^{\circ} \mathrm{C}$ for 12 hrs and milled.

\subsection{Proximate Analysis}

Moisture, ash, crude protein, fat, and crude fiber contents of the processed cassava leaves were determined using the AOAC [10] method while carbohydrate content was determined by difference.

\subsection{Mineral Analysis}

Mineral elements of the processed cassava leaves were analyzed for magnesium, calcium, zinc and iron using an Atomic Absorption Spectrophotometer, AAS (Model 372, PerkinElmer, Beaconsfield, U.K.) according to the procedure of AOAC [10] method.

\subsection{Anti-nutritional Analysis}

Tannin, phytate, oxalate, total saponins and alkaloid were determined according to Pearson [11]. 


\subsection{Statistical Analysis}

The data obtained were subjected to analysis of variance (ANOVA) using Minitab®, version 16 software. All analysis was done in duplicate using Duncan Multiple Test Range (DMRT) for means separation at $5 \%$ probability level $(\mathrm{p}>0.05)$.

\section{RESULTS AND DISCUSSION}

\subsection{Effect of Processing on the Proximate Composition of Cassava Leaves}

Results of the proximate composition of bitter and sweet cassava leaves are shown in Table 1. Moisture content of the cassava leaves ranged from 56.51-87.11\%. Moisture content was highest in the boiled sweet cassava leaves and this was not significantly $(p>0.05)$ different from moisture content of boiled bitter cassava leaves. The moisture content of the sweet cassava leaves for each processing method did not differ significantly $(p>0.05)$ from the moisture content of bitter cassava leaves except for the sweet and bitter dry-roasted cassava leaves which differed significantly $(p<0.05)$ from each other. Moisture content was observed to be lowest in the microwaved sweet and bitter cassava leaves. This trend was also reported by Bembem and Sadana [12] that moisture content of microwaved potatoes $(70.45 \%)$ was highest as compared to steamed $(78.56 \%)$, boiled $(79.16 \%)$ and raw sample $(76.52 \%)$. The decrease in moisture content during microwaving is caused by loss of water through evaporation [13].

Ash content of the cassava leaves ranged from $0.74-3.28 \%$ with the microwaved sample resulting to higher ash content (3.28 and $2.74 \%$ for sweet and bitter cassava leaves, respectively) while the boiled sample $(0.77$ and $0.74 \%$ for sweet and bitter cassava leaves, respectively) resulted to a lower value relative to other processing methods. This same trend was also reported by Bembem and Sudana [12] who observed that the ash content of microwaved potatoes $(1.08 \%)$ was highest when compared to steaming $(0.78 \%)$, boiling $(0.76 \%)$ and raw sample $(0.89 \%)$.

An increasing trend of fat content in the cassava leaves was observed in the manner: boiling $>$ steaming $>$ dry roasting $>$ microwaving. This shows that heating frees the crude fat from the cassava leaves matrices as compared to the fresh leaves. Microwaving resulted to a higher increase in the fat content (1.50 and $2.29 \%$ for sweet and bitter cassava leaves, respectively) while boiling (0.91 and $0.94 \%$ for sweet and bitter cassava leaves, respectively) was lowest relative to other processing methods. This study agrees with the findings of Bembem and Sudana [12] who reported that the fat content of microwaved potatoes $(0.15 \%)$ was highest when compared to steaming $(0.10 \%)$, boiling $(0.10 \%)$ and raw sample $(0.11 \%)$.

Microwaving resulted to a higher increase in crude fibre (12.77 and 10.175 for sweet and bitter cassava leaves, respectively) while boiling was lowest (4.38 and $2.29 \%$ for sweet and bitter cassava leaves, respectively) relative to other processing methods. This study also agrees with the findings of Bembem and Sudana [12] who reported that the crude fibre content of microwaved potatoes $(0.59 \%)$ was highest when compared to steaming $(0.50 \%)$, boiling $(0.40 \%)$ and raw sample $(0.42 \%)$.

Percentage decrease in crude protein values for sweet cassava leaves were $11.38,7.75,6.94$, 4.99 and $4.99 \%$ for microwaving, dry roasting, fresh cassava leaves, steaming and boiling, respectively. Percentage decrease in protein content of the bitter cassava leaves were 12.08, $8.41,6.51,5.42$, and $4.40 \%$ for microwaving, dry roasting, fresh leaves, steaming and boiling, respectively. Protein content of the leaves was higher in microwaved samples while boiling method gave the least. This probably suggests that the boiling water used resulted to leaching proteins in the boiled cassava leaves. The increase in the protein content by microwaving might be due to the reduction in the moisture content by this method. Decreased moisture content has been described as the most important change causing significant increase in protein in foods. Ersoy and Ozeren [14] pointed that increase in protein after different cooking methods could be explained by water reduction, indicating an inverse relationship between water content and other nutritional components. This study agrees with the findings of Bembem and Sudana (2013) who reported that the protein content of microwaved potatoes $(2.36 \%)$ was highest when compared to steaming $(1.62 \%)$, boiling (1.53\%) and raw sample (1.97\%).

A decreasing trend in carbohydrate content was observed for the different processing methods in the following manner: microwaving $>$ dry roasting $>$ steaming $>$ boiling. Microwaving in this case retains the highest amount of carbohydrate while losses in carbohydrate were high in the boiled samples. This may be as a result of some of carbohydrate dissolving in the 
large volume of water in the boiling method [15]. This study is in agreement with the findings of Okibe et al. [16] who reported that microwaving retains the highest amount of carbohydrate in fluted pumpkin leaves as compared to steaming and boiling. Bembem and Sudana [12] also reported that the carbohydrate content of microwaved potatoes $(25.25 \%)$ was highest when compared to steaming $(18.50 \%)$, boiling (18.05\%) and raw sample (20.00\%).

Table1. Proximate composition of Cassava leaves from different processing methods

\begin{tabular}{|c|c|c|c|c|c|c|}
\hline Sample & Moisture (\%) & Ash (\%) & Fat (\%) & Crude fibre (\%) & Protein (\%) & CHO (\%) \\
\hline MWSCL & $58.14 \pm 0.80^{\mathrm{f}}$ & $3.28 \pm 0.16^{\mathrm{a}}$ & $1.50 \pm 0.26 \mathrm{c}$ & $12.77 \pm 0.48^{\mathrm{a}}$ & $11.38 \pm 0.35^{\mathrm{b}}$ & $12.95 \pm 0.49^{\mathrm{bc}}$ \\
\hline SSCL & $81.70 \pm 1.22^{\mathrm{b}}$ & $1.23 \pm 0.13^{\mathrm{e}}$ & $1.02 \pm 0.05^{\mathrm{ef}}$ & $4.45 \pm 0.35^{\mathrm{de}}$ & $4.99 \pm 0.39^{\mathrm{fg}}$ & $6.60 \pm 0.99^{\mathrm{d}}$ \\
\hline BSCL & $87.11 \pm 0.91^{\mathrm{a}}$ & $0.77 \pm 0.57^{\mathrm{f}}$ & $0.91 \pm 0.06^{\mathrm{f}}$ & $4.38 \pm 0.34^{\mathrm{de}}$ & $3.82 \pm 0.20^{\mathrm{h}}$ & $3.00 \pm 0.28^{\mathrm{e}}$ \\
\hline DRSCL & $72.79 \pm 1.87^{\mathrm{d}}$ & $2.08 \pm 0.12^{\mathrm{c}}$ & $1.35 \pm 0.01^{\mathrm{cd}}$ & $5.40 \pm 0.90^{\mathrm{d}}$ & $7.75 \pm 0.45^{\mathrm{d}}$ & $10.65 \pm 2.19^{\mathrm{c}}$ \\
\hline FSCL & $76.20 \pm 0.20^{\mathrm{c}}$ & $2.02 \pm 0.08^{\mathrm{c}}$ & $0.85 \pm 0.13^{\mathrm{f}}$ & $10.17 \pm 0.99^{\mathrm{b}}$ & $6.94 \pm 0.06^{\mathrm{e}}$ & $3.82 \pm 1.20^{\mathrm{e}}$ \\
\hline MWBCL & $56.51 \pm 1.18^{\mathrm{f}}$ & $2.74 \pm 0.13^{\mathrm{b}}$ & $2.29 \pm 0.13^{\mathrm{a}}$ & $6.92 \pm 0.21^{\mathrm{c}}$ & $12.08 \pm 0.20^{\mathrm{a}}$ & $19.45 \pm 0.92^{\mathrm{a}}$ \\
\hline SBCL & $81.49 \pm 1.09^{\mathrm{b}}$ & $1.14 \pm 0.04^{\mathrm{e}}$ & $0.98 \pm 0.09^{\mathrm{ef}}$ & $3.67 \pm 0.74^{\mathrm{e}}$ & $5.42 \pm 0.32^{\mathrm{f}}$ & $7.30 \pm 1.41^{\mathrm{d}}$ \\
\hline BBCL & $85.08 \pm 0.26^{\mathrm{a}}$ & $0.74 \pm 0.03^{\mathrm{f}}$ & $0.94 \pm 0.00^{\mathrm{f}}$ & $2.29 \pm 0.17^{\mathrm{f}}$ & $4.40 \pm 0.12^{\mathrm{gh}}$ & $6.55 \pm 0.07^{\mathrm{d}}$ \\
\hline DRBCL & $70.14 \pm 0.39^{\mathrm{e}}$ & $1.70 \pm 0.14^{\mathrm{d}}$ & $1.94 \pm 0.00^{\mathrm{b}}$ & $3.99 \pm 0.04^{\mathrm{e}}$ & $8.41 \pm 0.01^{\mathrm{c}}$ & $13.80 \pm 0.42^{\mathrm{b}}$ \\
\hline FBCL & $76.85 \pm 1.32^{\mathrm{c}}$ & $1.61 \pm 0.08^{\mathrm{d}}$ & $1.23 \pm 0.00^{\mathrm{de}}$ & $3.16 \pm 0.30^{\mathrm{ef}}$ & $6.51 \pm 0.30^{\mathrm{e}}$ & $3.15 \pm 0.35^{\mathrm{e}}$ \\
\hline
\end{tabular}

Values are expressed as mean \pm standard deviation of duplicate determination. Means with the same letters along the same column are not significantly different $(p>0.05)$.

KEYS: $M W S C L=$ Microwaved sweet cassava leaves, $S S C L=$ Steamed sweet cassava leaves, $B S C L=$ Boiled sweet cassava leaves, DRSCL = Dried roasted sweet cassava leaves, $F S C L=$ Fresh sweet cassava leaves, $M W B C L=$ Microwaved bitter cassava leaves, $S B C L=$ Steamed bitter cassava leaves, $B B C L=$ Boiled bitter cassava leaves, $D R B C L=$ Dried roasted bitter cassava leaves, $F B C L=$ Fresh bitter cassava leaves

\subsection{Effect of Processing on the Mineral composition of Cassava leaves}

Table 2 presents the mineral composition of sweet and bitter cassava leaves as affected by processing methods. Results showed that the percentage decrease in magnesium (1.50$0.44 \mathrm{mg} / 100 \mathrm{~g})$ and calcium (105.69$31.94 \mathrm{mg} / 100 \mathrm{~g}$ ) was highest for boiling while the microwaving gave the highest content relative to other method of processing. Results also showed that percentage decrease in potassium (43.40$9.59 \mathrm{mg} / 100 \mathrm{~g}$ ) and iron $(5.11-1.30 \mathrm{mg} / 100 \mathrm{~g})$ was lowest for steaming and highest for microwaving as compared to other processing methods. The decreasing trend in the zinc content of the cassava leaves was observed in this manner: fresh>dry roasting> microwaving> steaming > boiling with values ranging from $1.81-0.49 \mathrm{mg} / 100 \mathrm{~g}$. This observation in the high losses of minerals for boiling method may be related to the large volume of water used in boiling and the water vapour in steaming method which may have resulted in the leaching and evaporation in these minerals. From the results of the mineral analysis, microwaving cassava leaves will retain more of the mineral content than steaming, boiling and dry roasting. This result is in concordance with the study of Okibe et al. [16] who reported that the percentage decrease in $\mathrm{P}, \mathrm{K}, \mathrm{Na}, \mathrm{Ca}, \mathrm{Mg}$ and $\mathrm{Fe}$ in Telfairia occidentalis was highest for the boiling method while microwaving retained more of the minerals.

Table2. Mineral composition of Cassava leaves from different processing methods

\begin{tabular}{|c|c|c|c|c|c|}
\hline Sample & $\begin{array}{c}\text { Mg } \\
(\mathbf{m g} / \mathbf{1 0 0 g})\end{array}$ & $\begin{array}{c}\text { Iron } \\
(\mathbf{m g} / \mathbf{1 0 0 g})\end{array}$ & $\begin{array}{c}\text { Zinc } \\
(\mathbf{m g} / \mathbf{1 0 0 g})\end{array}$ & $\begin{array}{c}\text { Calcium } \\
(\mathbf{m g} / \mathbf{1 0 0 g})\end{array}$ & $\begin{array}{c}\text { Potassium } \\
(\mathbf{m g} / \mathbf{1 0 0 g})\end{array}$ \\
\hline MWSCL & $1.41 \pm 0.00^{\mathrm{b}}$ & $5.11 \pm 0.00^{\mathrm{a}}$ & $0.64 \pm 0.26^{\mathrm{f}}$ & $96.52 \pm 0.07^{\mathrm{b}}$ & $38.46 \pm 0.00^{\mathrm{b}}$ \\
\hline SSCL & $0.59 \pm 0.00^{\mathrm{h}}$ & $1.30 \pm 0.01^{\mathrm{f}}$ & $0.49 \pm 0.05^{\mathrm{f}}$ & $41.11 \pm 0.04^{\mathrm{h}}$ & $9.59 \pm 0.01^{\mathrm{g}}$ \\
\hline BSCL & $0.44 \pm 0.00^{\mathrm{j}}$ & $1.36 \pm 0.01^{\mathrm{f}}$ & $0.66 \pm 0.06^{\mathrm{ef}}$ & $31.94 \pm 0.00^{\mathrm{i}}$ & $12.46 \pm 0.00^{\mathrm{j}}$ \\
\hline DRSCL & $0.88 \pm 0.00^{\mathrm{d}}$ & $2.20 \pm 0.01^{\mathrm{cd}}$ & $0.95 \pm 0.01^{\mathrm{d}}$ & $63.79 \pm 0.05^{\mathrm{d}}$ & $25.96 \pm 0.01^{\mathrm{d}}$ \\
\hline FSCL & $0.79 \pm 0.00^{\mathrm{e}}$ & $2.18 \pm 0.01^{\mathrm{cd}}$ & $1.74 \pm 0.13^{\mathrm{b}}$ & $58.82 \pm 0.05^{\mathrm{e}}$ & $23.42 \pm 0.00^{\mathrm{e}}$ \\
\hline MWBCL & $1.51 \pm 0.00^{\mathrm{a}}$ & $4.94 \pm 0.03^{\mathrm{a}}$ & $1.42 \pm 0.13^{\mathrm{c}}$ & $105.69 \pm 0.09^{\mathrm{a}}$ & $43.40 \pm 0.00^{\mathrm{a}}$ \\
\hline SBCL & $0.61 \pm 0.00^{\mathrm{g}}$ & $1.90 \pm 0.03^{\mathrm{de}}$ & $1.40 \pm 0.28^{\mathrm{c}}$ & $43.79 \pm 0.04^{\mathrm{g}}$ & $19.21 \pm 0.00 \mathrm{~h}$ \\
\hline BBCL & $0.51 \pm 0.00^{\mathrm{i}}$ & $1.76 \pm 0.01^{\mathrm{e}}$ & $0.82 \pm 0.00^{\mathrm{de}}$ & $43.80 \pm 0.03^{\mathrm{g}}$ & $15.94 \pm 0.00^{\mathrm{i}}$ \\
\hline DRBCL & $1.01 \pm 0.00^{\mathrm{c}}$ & $3.64 \pm 0.02^{\mathrm{b}}$ & $1.74 \pm 0.00^{\mathrm{b}}$ & $69.47 \pm 0.06^{\mathrm{c}}$ & $31.89 \pm 0.21^{\mathrm{c}}$ \\
\hline FBCL & $0.74 \pm 0.00^{\mathrm{f}}$ & $2.50 \pm 0.43^{\mathrm{c}}$ & $1.81 \pm 0.01^{\mathrm{a}}$ & $57.72 \pm 0.04^{\mathrm{f}}$ & $21.04 \pm 0.00^{\mathrm{f}}$ \\
\hline
\end{tabular}


Values are expressed as mean \pm standard deviation of duplicate determination. Means with the same letters along the same column are not significantly different $(p>0.05)$.

KEYS: $M W S C L=$ Microwaved sweet cassava leaves, SSCL= Steamed sweet cassava leaves, BSCL= Boiled sweet cassava leaves, DRSCL= Dried roasted sweet cassava leaves, FSCL=Fresh sweet cassava leaves, $M W B C L=$ Microwaved bitter cassava leaves, $S B C L=$ Steamed bitter cassava leaves, BBCL= Boiled bitter cassava leaves, DRBCL= Dried roasted bitter cassava leaves, $F B C L=$ Fresh bitter cassava leaves

\subsection{Effect of Processing Methods on the Anti-nutritional Factors of Cassava Leaves}

The anti-nutritional factors of sweet and bitter cassava leaves are shown in Table 3. Phytate content of the cassava leaves ranged from 0.92$4.12 \mathrm{mg} / \mathrm{kg}$ and was significantly $(\mathrm{p}<0.05)$ increased by the processing methods except for boiling and steaming methods. A decreasing trend in the phytate content of cassava leaves was observed for the different processing methods in the following manner: boiling> steaming $>$ dry roasting $>$ microwaving. Microwaving resulted to a higher increase (4.12 and $2.89 \mathrm{mg} / \mathrm{kg}$ for sweet and bitter cassava leaves, respectively) while boiling resulted to a lower value $(0.96$ and $0.91 \mathrm{mg} / \mathrm{kg}$ for sweet and bitter cassava leaves, respectively) relative to other processing methods. Hence, it is imperative to suggest that cassava leaves should be properly processed before consumption, by either boiling or steaming. Omosuli [4] also reported a decrease in anti-nutritional factors of cassava tubers during boiling and this was attributed to leaching into the boiling water. Rehman and Shah [17] also stated that simple boiling results to the reduction of anti-nutrients in food. The decrease in phytate content during boiling from this study is also due to leaching out of this compound in water [18]. Phytates can reduce bioavailability of minerals; impaired protein digestibility caused by formation of phytic-protein complexes and depressed absorption of nutrients [19]. The determination of phytate was of interest due to their negative effects on mineral bioavailability.

Oxalate content of the cassava leaves ranged from $0.52-1.62 \mathrm{mg} / \mathrm{kg}$ and was significantly $(\mathrm{p}<0.05)$ increased by the processing methods except for boiling and steaming. Microwaving resulted to a higher increase in oxalate content (1.62 and $1.12 \%$ for bitter and sweet cassava leaves, respectively) while boiling resulted to a low oxalate content $(1.48$ and $0.52 \mathrm{mg} / \mathrm{kg}$ for bitter and sweet cassava leaves, respectively) relative to other processing methods. Savage and Martensson [20] reported that when taro samples were boiled in water, oxalate content decreased by at least $47 \%$. Oxalates are known to complex with calcium to form calcium crystals which get deposited as stones that are associated with blockage of renal tubules [21].

Tannic acid content of the cassava leaves ranged from $0.22-1.52 \mathrm{mg} / \mathrm{kg}$ and was significantly $(\mathrm{p}<0.05)$ increased for all the processing methods except for boiling and steaming. Microwaving resulted to a higher increase (1.52 and $1.42 \mathrm{mg} / \mathrm{kg}$ for sweet and bitter cassava leaves, respectively) while steaming $(0.22 \mathrm{mg} / \mathrm{kg}$ for sweet cassava leaves) and boiling $(0.54 \mathrm{mg} / \mathrm{kg}$ for bitter cassava leaves) resulted to a decrease. Loss of tannin may be due to its solubility in water and its sensititvity to heat during boiling [22]. Tannins have the ability to complex with vitamin B12 (Francis et al., 2001) and also interfere with the digestive processes either by binding enzymes or by binding to feed components like proteins or minerals [23].

Hydrogen cyanide content of the leaves ranged from $0.002-0.009 \mathrm{mg} / \mathrm{kg}$ and was highest in the dry-roasted cassava leaves. However, processing methods had no significant ( $p>0.05$ ) effect on the cyanide content. The cyanide content was low when compared with the study of Agbaire [24] for some local vegetables. The $\mathrm{HCN}$ is soluble in boiling water as such was leached out in the atmosphere [25]. Knowing the health implications of these anti-nutritional factors to man and livestock, the reduction in the levels of anti-nutritional factors during processing of cassava leaves is very vital for its safety. The anti-nutritional factors from this study were low and may not pose any serious nutritional problems when these leaves are consumed. Therefore, the consumption of cassava leaves is encouraged. 
Effect of Processing on the Chemical and Anti-Nutritional Properties of Cassava Leaves (Sweet and Bitter Varieties)

Table3. Anti-nutrient content of Cassava leaves from different processing methods

\begin{tabular}{|c|c|c|c|c|}
\hline Sample & $\begin{array}{c}\text { Phytate } \\
(\mathbf{m g} / \mathbf{k g})\end{array}$ & $\begin{array}{c}\text { Oxalate } \\
(\mathbf{m g} / \mathbf{k g})\end{array}$ & $\begin{array}{c}\text { Tannic acid } \\
(\mathbf{m g} / \mathbf{k g})\end{array}$ & $\begin{array}{c}\text { HCN } \\
(\mathbf{m g} / \mathbf{k g})\end{array}$ \\
\hline MWSCL & $4.12 \pm 0.06^{\mathrm{a}}$ & $1.12 \pm 0.05^{\mathrm{c}}$ & $1.52 \pm 0.00^{\mathrm{a}}$ & $0.003 \pm 0.00^{\mathrm{ab}}$ \\
\hline SSCL & $1.12 \pm 0.08^{\mathrm{f}}$ & $0.66 \pm 0.02^{\mathrm{f}}$ & $0.22 \pm 0.01^{\mathrm{i}}$ & $0.002 \pm 0.00^{\mathrm{ab}}$ \\
\hline BSCL & $0.96 \pm 0.05^{\mathrm{f}}$ & $0.52 \pm 0.09^{\mathrm{g}}$ & $0.44 \pm 0.07^{\mathrm{h}}$ & $0.002 \pm 0.00^{\mathrm{ab}}$ \\
\hline DRSCL & $2.33 \pm 0.16^{\mathrm{c}}$ & $1.23 \pm 0.07^{\mathrm{c}}$ & $0.98 \pm 0.07^{\mathrm{d}}$ & $0.009 \pm 0.00^{\mathrm{a}}$ \\
\hline FSCL & $2.16 \pm 0.20^{\mathrm{cd}}$ & $0.77 \pm 0.02^{\mathrm{ef}}$ & $0.92 \pm 0.01^{\mathrm{de}}$ & $0.003 \pm 0.00^{\mathrm{ab}}$ \\
\hline MWBCL & $2.89 \pm 0.39^{\mathrm{b}}$ & $1.62 \pm 0.04^{\mathrm{a}}$ & $1.42 \pm 0.08^{\mathrm{b}}$ & $0.006 \pm 0.00^{\mathrm{ab}}$ \\
\hline SBCL & $1.01 \pm 0.10^{\mathrm{f}}$ & $0.87 \pm 0.07^{\mathrm{de}}$ & $0.75 \pm 0.04^{\mathrm{f}}$ & $0.003 \pm 0.00^{\mathrm{ab}}$ \\
\hline BBCL & $0.91 \pm 0.03^{\mathrm{f}}$ & $0.44 \pm 0.01^{\mathrm{g}}$ & $0.54 \pm 0.01^{\mathrm{g}}$ & $0.002 \pm 0.00^{\mathrm{ab}}$ \\
\hline DRBCL & $1.64 \pm 0.24^{\mathrm{e}}$ & $1.48 \pm 0.02^{\mathrm{b}}$ & $1.33 \pm 0.03^{\mathrm{c}}$ & $0.007 \pm 0.00^{\mathrm{b}}$ \\
\hline FBCL & $1.84 \pm 0.31^{\mathrm{de}}$ & $0.94 \pm 0.10^{\mathrm{c}}$ & $0.85 \pm 0.05^{\mathrm{c}}$ & $0.003 \pm 0.00^{\mathrm{b}}$ \\
\hline
\end{tabular}

Values are expressed as mean \pm standard deviation of duplicate determination. Means with the same letters along the same column are not significantly different $(p>0.05)$.

KEYS: $M W S C L=$ Microwaved sweet cassava leaves, SSCL= Steamed sweet cassava leaves, BSCL= Boiled sweet cassava leaves, DRSCL= Dried roasted sweet cassava leaves, FSCL= Fresh sweet cassava leaves, $M W B C L=$ Microwaved bitter cassava leaves, $S B C L=$ Steamed bitter cassava leaves, BBCL= Boiled bitter cassava leaves, DRBCL= Dried roasted bitter cassava leaves, $F B C L=$ Fresh bitter cassava leaves

\section{Conclusion}

The protein, carbohydrate, crude fibre and ash contents of cassava leaves were significantly increased on the application of microwaving while the moisture content decreased relating to other processing methods. The mineral content of the cassava leaves were significantly higher by microwaving whereas boiling resulted to a great loss in these nutrients. However, the antinutrient content of the microwaved cassava leaves were higher than for other processing methods but were still within acceptable levels for consumption while boiling resulted to a loss in these compounds. On the whole, this study recommended microwaving as the most appropriate and suitable processing method for cassava leaves for optimum nutritional benefits with acceptable anti-nutritional factors. This method can also be explored as a cost-effective and less energy efficient way to reduce antinutrients and improve nutritional value of cassava leaves.

\section{REFERENCES}

[1] Cock, J.H. (1985). Cassava: New potential for neglected crop. Boulder, Colorado, USA, West View Press.

[2] Fasuyi, A.O. (2005). Nutrient composition and processing effects on cassava leaf (Manihot esculenta crantz) anti-nutrients. Pakistan Journal of Nutrition, 4: 37-42.

[3] Subbarao, G.V., Ito, O., Serraj, R., Crouch, J.J. and Tobita, S. (2005). Physiological perspectives on improving crop adaptation to drough-justification for a systematic component-based approach. In: Handbook of photosynthesis. Pessaraki.M. (Ed.). $2^{\text {nd }}$ Edn., Marcel and Dekker, New York, USA., pp: 577594.

[4] Omosuli, S.V. (2014). Effects of processing on the chemical and anti-nutritional properties of cassava roots. Research and Reviews: Journal of Botanical Sciences, 3(2): 27-31.

[5] Oresegun, A., Fagbenro, O.A., Ilona, P. and Bernard, E. (2016). Nutritional and antinutritional composition of cassava leaf protein concentrate from six cassava varieties for use in aqua feed. Cogent Food and Agriculture, 2:1147323.

http://dx.org/10.1080/23311932.2016.1147323.

[6] Jamil, S.S. and Bujang, A. (2016). Nutrient and anti-nutrient composition of different variety of cassava (Manihot esculentua Crantz) leaves. Jurnal Teknologi, 78 (6-6): 59-63.

[7] Ngudi, D.D., Kuo, Y.H. and Lambein, F. (2003). Cassava cyanogens and free amino acids in raw and cooked leaves. Food Chem. Toxicol. 41: 1193-1197.

[8] Ravindran, G. and Ravindran, V. (1988). Changes in the nutritional composition of cassava (Manihot esculenta crantz) leaves during maturity. Food Chemistry, 27: 299-309.

[9] Bradbury, J.H. and Denton, I.C. (2010). Simple method to reduce the cyanogens content of gari made from cassava. Food Chemistry, 123(3): 840-845.

[10] AOAC (2012). Association of Official Analytical Chemists. Official Method of Analysis of the AOAC. $20^{\text {th }}$ Ed, Washington; D.C.

[11] Pearson, D. (1976). The chemical analysis of food. $7^{\text {th }}$ Edition, Churchill, London. Pp. 6-16. 
[12] Bembem, K. and Sadana, B. (2013). Effect of cooking methods on the nutritional composition and antioxidant activity of potato tubers. International Journal of Food and Nutritional Sciences, 2(4): 26-29.

[13] Weber, J., Bochi, V., Ribeiro, C., Victorio, A. and Emmanuelli, T. (2008). Effect of different cooking methods on the oxidation, proximate and fatty acid composition of silver cat fish (Rhamdiaquelen) fillets. Food Chemistry, 106: 140-146.

[14] Ersoy, B. and Ozeren, A. (2009). The effect of cooking methods on mineral and vitamin content of African cat fish. Food Chemistry, 115: 419-422.

[15] Morris, A., Bametta, A. and Burows, O.J. (2004). Effect of processing on nutrient content of foods, Cajarticles, 37(3): 160-164.

[16] Okibe, F.G., Jubril, B., Paul, G.A., Shallangwa, and Dallatu, Y.A. (2016).Effect of cooking methods on the proximate and mineral composition of fluted pumpkin (Telfairia occidentalis) leaves. International Journal of Biochemistry. Res. Rev. 9:1-7.

[17] Rehman, Z.U. and Shah, W.H (2005).Thermal heat processing effect on anti-nutrients, protein and starch digestibility of food legumes. Food Chemistry: 91, 327-331.

[18] Osman, A.M. (2007). Effect of different processing methods on nutrient composition, anti-nutritional factors and invitro protein digestibility on Dolichos lablab bean (lablab purpurpureus) (L) sweet). Pakistan Journal of Nutrition, 6(4): 299-303.

[19] Francis G., Makkar H.P.S., and Becker, K. (2001). Anti-nutritional factors present in plant derived alternative fish feed ingredients and their effects in fish. Aquaculture 199: 197- 227.

[20] Savage, G.P. and Martensson, L. (2010). Composition of the estimates of the oxalate content of taro leaves and corms and a selection of Indian vegetables following hot water, hot acid and invitro extraction methods. Journal of Food Composition and Analysis, 23: 113-117.

[21] Banso A, and Adeyemo, S.O. (2007). Evaluation of antimicrobial properties of tannins isolated from Dichrostachyscinerea. African Journal of Biotechnology 6 (15):17851787.

[22] Esenwah, C.N. and Ikenebomeh, M.J. (2008). Processing effects on the nutritional and antinutritional contents of African locust bean (Parkiabiglobosa Benth). Pakistan Journal of Nutrition, 7(2): 214-217.

[23] Hagerman, A. E., Robbin, C.T., Weerasuriya, Y., Wilson, T.C. and McArthur, C., (1992).Tannin chemistry in relation to digestion. J. Range Management (USA) 45 (1): 57-62.

[24] Agbaire, P.O. (2011). Nutritional and antinutritional levels of some local vegetables (Vernomia amydalira), Manihot esculenta, Teiferia, occidentalis, Talinum trianguare, Amyranthus spinosus) from Delta State, Nigeria. J. Appl. Sci. Environ. Manage. 15(4): 625-628.

[25] Ikemefuna, C., Obizoba, J. and Atii, J.V. (1991).Effects of soaking, sprouting, fermentation and cooking on nutrient composition and some anti-nutritional factors of sorghum (Guinesia) seeds. Plant foods for Human Nutrition, 41: 203-212.

Citation: Ujong Anim Ekpo, Deede Faith Baridia. Effect of Processing on the Chemical and Anti-Nutritional Properties of Cassava Leaves (Sweet and Bitter Varieties). ARC Journal of Nutrition and Growth. 2020; 6(2):6-12. DOI: https://doi.org/10.20431/2455-2550.0602002.

Copyright: (c) 2020 Authors. This is an open-access article distributed under the terms of the Creative Commons Attribution License, which permits unrestricted use, distribution, and reproduction in any medium, provided the original author and source are credited. 